Журнал «Герспективитаінноваціїнауки»

(Серія «Педагогіка», Серія «Гиихологія», Серія«Медицина»

№5(5) 2021

УДК: 378:37.013.42-051

https://doi.org/10.52058/2786-4952-2021-5(5)-688-700

Шевченко Жанна Михайлівна кандидат педагогічних наук, старший викладач кафедри соціології та соціальної роботи Інституту гуманітарних та соціальних наук, Національний університет «Львівська політехніка», вул. Коновальця 4, 29-й н. к., м. Львів, 79000, тел.: (067) 773-53-57, e-mail: zhannaostap@ukr.net, https://orcid.org/0000-0002-4019-639X

\title{
ЕКСТРАПОЛЯЦІЯ ВИКОРИСТАННЯ ПОЗИТИВНОГО ДОСВІДУ ПРАКТИЧНОЇ ПІДГОТОВКИ СОЦІАЛЬНИХ ПРАЦІВНИКІВ ПОЛЬЩІ У ВІТЧИЗНЯНІЙ ВИЩІЙ ШКОЛІ
}

Анотація. У статті здійснено екстраполяцію використання позитивного досвіду практичної підготовки соціальних працівників у Республіці Польща у вітчизняній вищій школі. Акцентовано увагу на тому, що перед сучасною вітчизняною вищою освітою постало досить складне завдання: зберегти всі позитивні здобутки та досвід української освіти i збагатити його інноваційними досягненнями європейських освітніх середовищ, гармонійно узгодити їх з українськими.

У ході дослідження виявлено позитивний досвід i здійснено аналіз практичних здобутків упровадження практичної підготовки соціальних працівників у вищій школі Польщі на рівні ліценціату та магістерських студій та окреслено можливості творчого використання позитивних надбань в освітньому процесі України. Визначено соціокультурні чинники практичного спрямування професійної підготовки соціальних працівників у польських вишах, відображено польський досвід щодо створення умов для практичного компоненту підготовки майбутніх соціальних працівників 3 профвідбору абітурієнтів на навчання за фахом «Соціальна робота».

Простежено тенденції науково-методичного супроводу кафедр соціальної роботи щодо практичної підготовки соціальних працівників: відповідність загальноєвропейській спрямованості до ранньої спеціальної підготовки всіх фахівців соціальної сфери; двосторонній зв'язок між розвитком наукової школи соціальної роботи та системою організації практичної підготовки; підготовка соціального працівника в навчальних закладах церкви; децентралізація управління професійною підготовкою; швидке реагування системи на зміни соціального характеру, запити регіонального ринку праці.

У теорії і практиці польських вишів у практичному спрямуванні освітнього процесу простежено дієвість державних програм, а також міжнародних фондів та громадських організацій і комітетів.

Ключові слова: польський досвід, соціальний працівник,науковометодичний супровід, практична підготовка. 
Shevchenko Zhanna Mykhailivna Candidate of Pedagogical Sciences, Senior Lecturer, Department of Sociology and Social Work, Institute of Humanities and Social Sciences, Lviv Polytechnic National University, Konovalets St. 4, 29th n. k., Lviv, 79000, tel.: (067) 773-53-57, e-mail: zhannaostap@ukr.net, https://orcid.org/0000-0002-4019-639X

\section{EXTRAPOLATION OF USING POSITIVE EXPERIENCE OF PRACTICAL TRAINING OF POLISH SOCIAL WORKERS IN HOMELAND HIGHER SCHOO}

Abstract. The article extrapolates the use of positive experience of practical training of social workers in the Republic of Poland in domestic higher education.Emphasis is placed on the fact that modern domestic higher education faces a rather difficult task: to preserve all the positive achievements and experience of Ukrainian education and enrich it with innovative achievements of European educational environments, to harmonize them with Ukrainian ones. The study revealed positive experience and analyzed the practical achievements of the implementation of practical training of social workers in higher education in Poland at the level of licentiate and master's studies and outlined opportunities for creative use of positive achievements in the educational process of Ukraine.

Socio-cultural factors of practical orientation of professional training of social workers in Polish universities are determined, the Polish experience in creating conditions for the practical component of training future social workers in the professional selection of entrants for training in "Social Work" is reflected.

The tendencies of scientific and methodical support of the departments of social work on the practical training of social workers are observed: compliance with the European orientation to the early special training of all specialists in the social sphere; bilateral connection between the development of the scientific school of social work and the system of organization of practical training; training of a social worker in church educational institutions; decentralization of vocational training management; rapid response of the system to changes in the social nature, the demands of the regional labor market.

In the theory and practice of Polish universities in the practical direction of the educational process traced the effectiveness of state programs, as well as international foundations and public organizations and committees.

Keywords: Polish experience, social worker, scientific and methodological support, practical training.

Постановка проблеми. Соціальні виклики в умовах світової інтеграції й посилення взаємодії країн актуалізують питання вивчення досвіду закладів вищої освіти міжнародного освітньо-наукового простору в соціальній сфері. Входження України в Болонський процес потребує радикальної модернізації змісту вищої освіти, лейтмотивом якої повинна стати ліквідація застарілих 
міфів, своєрідної ідеологізації освіти, притаманної тоталітарному суспільству, наближення до реального історичного процесу, сучасних соціокультурних реалій та прогнозованого майбутнього $[1$, с. 7]. Разом із тим, кожна країнаучасниця повинна зберегти національну палітру, самобутність та надбання у змісті освіти й підготовці фахівців 3 вищою освітою, а далі запровадити інноваційні та прогресивні підходи до організації вищої освіти, які властиві європейському простору вищої освіти. Вважаємо, що удосконалення системи практичної підготовки соціальних працівників в Україні, іiі розвиток адекватно до європейських стандартів можливий за умови активного вивчення прогресивних ідей зарубіжного досвіду підготовки відповідних фахівців у практику роботи ЗВО. Перед сучасною вищою освітою постало досить складне завдання: зберегти всі позитивні здобутки та досвід української освіти і збагатити його інноваційними досягненнями європейських освітніх середовищ, гармонійно узгодити їх з українськими [2, с. 31].

Аналіз останніх досліджень і публікацій. Актуальні аспекти проблеми практичної підготовки фахівців для соціально-педагогічної діяльності розглядають українські й польські науковці за такими напрямами: теорія $i$ практика підготовки фахівиів у галузі соиіально-педагогічної діяльності (В. Беспалько, І. Вільш, Р. Вайнола, М. Гревінський, Н. Квянтковська, Г. Ніколаї, В. Поліщук, Л. Пуховська, Н. Сейко, С. Харченко); сочіальнопедагогічні аспекти історико-педагогічних досліджень (О. Адаменко, С. Бадора, Л. Березівська, Ю. Борисова, Л. Голубнича, Д. Травковська, I. Мельничук, I. Мищишин, Ю. Поліщук, Б. Скржипчак, О. Сухомлинська, Я. Хрінкевич); теоретичні засади соиіальної педагогіки (Р. Врочинський, Т. Жолковська, І. Звєрєва, А. Капська, Л. Коваль, С. Когут, Г. Лактіонова); теорія компаративних досліджень (Ф. Андрушкевич, Н. Гайдук, С. Когут, M. Коморська). Вітчизняні науковці наголошують на необхідності удосконалення практичної підготовки соціальних працівників в Україні: Т. Абрамович (2018); В. Бенера (2019), О. Карпенко (2008); В. Поліщук (2010); 3. Фалинська (2006) та ін.

Вивчення вітчизняних науково-педагогічних праць і досліджень, у яких розглядаються системи освіти зарубіжних країн, показало, що проблема практичної підготовки соціального працівника в умовах польського освітнього виміру на тлі сучасних глобалізаційних процесів не набула ознак завершеного й докладного розгляду. Зокрема, не $\epsilon$ виокремленими релевантні для українського освітнього контексту елементи позитивного досвіду практичної підготовки соціального працівника у вищій школі Польщі, що і визначило мету cmammi: здійснити екстраполяцію використання позитивного досвіду практичної підготовки соціальних працівників у Республіці Польща у вітчизняній вищій школі.

Виклад основного матеріалу. При виробленні стратегії розвитку практичної підготовки соціальних працівників у ЗВО в Україні особливо важливим $є$ досвід розвитку вищої педагогічної освіти Республіки Польща, яка 
зробила європейський вибір. Практика регулювання державою соціальних проблем у Польщі набула поширення з початку XX ст. Місце соціальної роботи у системі соціальної політики Республіки Польща розглядаємо у логічному взаємозв'язку складових детермінант: соціальна політика соціальне забезпечення - соціальна допомога - соціальна робота. Соціальна робота $\epsilon$ складовою соціального забезпечення, що належить до системи соціальної політики. Організаційно системи підготовки майбутніх фахівців соціальної роботи України і Польщі досить схожі - вони здійснюється на засадах неперервності (допрофесійне, професійне, післядипломне навчання) та багаторівневості (бакалавр, магістр, доктор філософії). Результативність практичної підготовки зумовлена значною мірою не тільки можливостями ЗВО, але й рівнем розвитку соціальної інфраструктури конкретного регіону й активністю взаємодії ЗВО з соціальними службами. Вважаємо за необхідне використання досвіду освітніх європейських практик індивідуалізації професійного відбору та персонального навчання, які відповідають викликам часу, сприяють подоланню суперечності між вимогами сучасності до особистості майбутнього фахівця соціальної сфери та традиційними освітніми практиками. Інтегральний комплекс соціокультурних чинників практичного спрямування у Польщі представлено на Схемі 1.

Важливим є досвід вищої школи Польщі з профвідбору абітурієнтів на навчання за фахом «Соціальна робота». Обов'язковими $\epsilon$ обгрунтування вступником вибору майбутньої професії, рекомендаційні листи від викладачів, кваліфікованих соціальних працівників, фахівців соціальних закладів і служб чи інших осіб, здатних оцінити потенціал абітурієнта. Упровадження $3 \mathrm{HO}$ в останні роки у системі вищої освіти України, попри свої позитивні сторони, практично нівелювало проведення співбесід та інших контактів щодо професійної приналежності майбутнього абітурієнта до напряму соціальна робота. Вважаємо, що допрофесійна підготовка соціального працівника, запроваджена в практику діяльності загальноосвітніх шкіл України, враховуючи запити та здібності учнів, а також потреби ринкового суспільства, відповідатиме як індивідуальним, так і суспільним інтересам [3;5]. Щоб внесок вищої школи у кадрове забезпечення перебудови соціальної сфери в Україні був дієвим і впливовим, слід здійснювати впровадження нових соціальних програм у теорію і практику соціального виховання сучасного фахівця на лінії допрофесійної підготовки.

Польські дослідники та практики відзначають, що децентралізація наближає Польщу до реалізації соціальної політики відповідно до принципу субсидіарності, але слід пам'ятати, що після 2004 р. країна також впроваджує принцип верховенства, що полягає у відведенні деяких компетенцій у сфері соціальної політики інституціям $\mathrm{CC}$, які гармонізують та координують певну сферу соціальної політики, у тому числі у сфері політики соціальної інтеграції. Така змішана модель сервісної організації має базуватися на концепції управління, де держава поділяє завдання і відповідальність за соціальні 
Журнал«Герспективита іновації наукиљ

(Серія«Гедагогіка», Серія«ГТихологія», Серія«Медицинв»

№5(5) 2021

питання 3 різними зацікавленими сторонами. Особливістю такої державної організаційної моделі є партнерські міжінституційні відносини, багаторівневе управління та координація рішень, спільне планування політики та програмування, широкі громадські консультації, створення мереж та тематичних груп, вирішення соціальних проблем у командах. Створення більш інтегрованої партнерської моделі соціальних послуг допоможуть подолати галузеві стереотипи, які існують у Польщі, та може бути цікавою для впровадження в Україні.

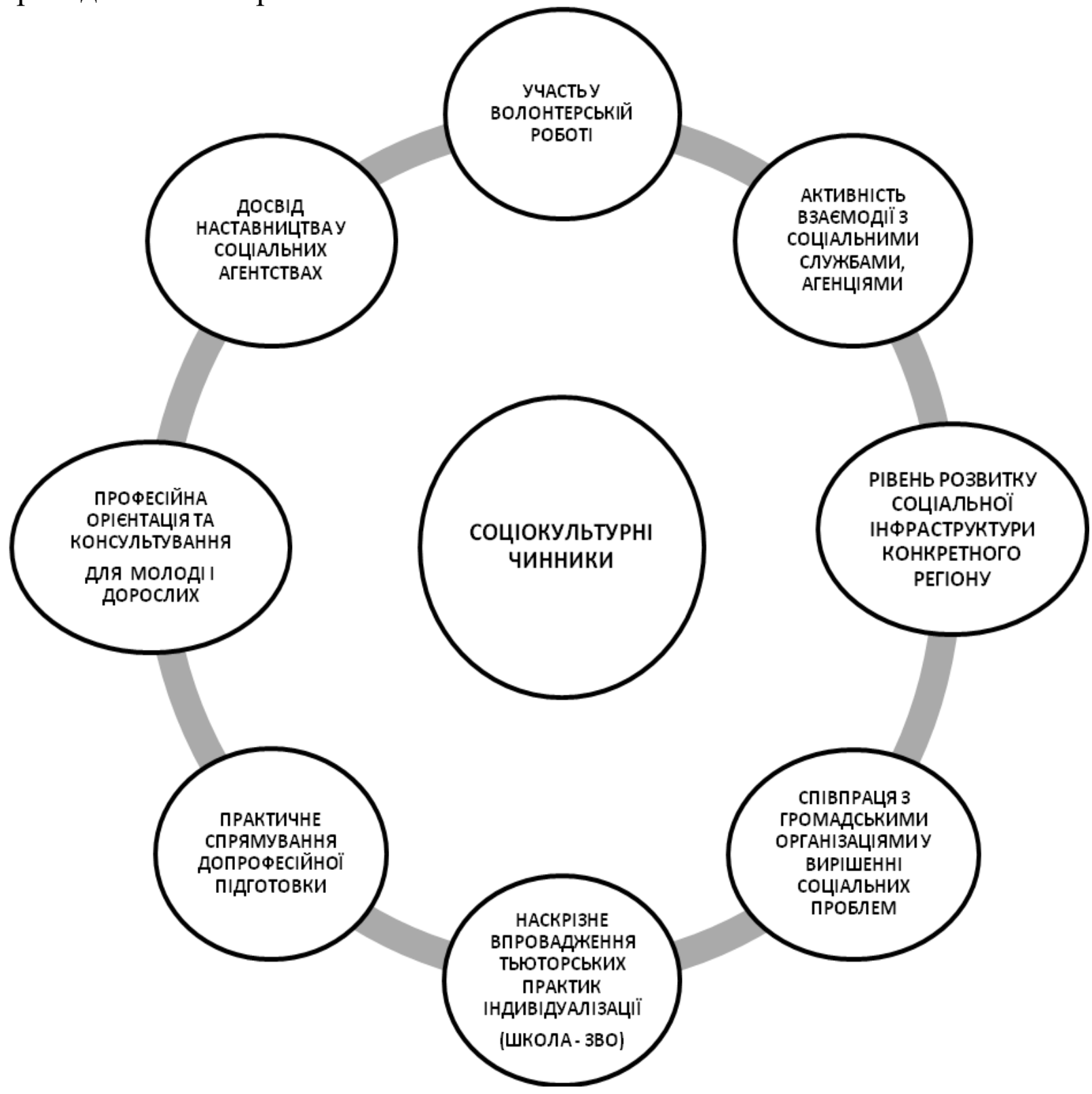

Рис. 1. Соціокультурні чинники практичного спрямування професійної підготовки соціальних працівників у Республіці Польщ̧а [4, с.200].

Система вищої освіти Республіки Польща за останні десятиліття пройшла складний шлях реформації, який доцільно взяти за зразок при реформуванні ЗВО України. Про необхідність практичної підготовки соціальних працівників в Україні засвідчують дані результатів дослідження, яке передбачало вивчення 
експертної думки фахівців [4; 6; 7; 8]. Так, 21\% фахівців відповіли про недостатність навчальних програм 3 практичної підготовки соціальних працівників до роботи 3 національними меншинами; на низький рівень фінансування програм роботи вказали $32 \%$ експертів; про відсутність налагодженої взаємодії з керівниками національних громад зазначили 12 \%; на розумінні сутності і важливості соціальної роботи 3 боку громадськості настоюють $12 \%$; про недостатність кваліфікації та знань соціальних працівників культурних особливостей вказали $17 \%$ фахівців. Отже, надзвичайно важливими $\epsilon$ інтенсифікаційні зміни в процесі підготовки соціальних працівників, які б мінімізували прогалини в практичній підготовці фахівців для соціальної сфери.

Відзначимо, що окремі аспекти польського досвіду практичної підготовки студентів до роботи 3 етнічними меншинами впродовж останніх років використовуються в Національному університеті «Львівська політехніка» (обов'язкове включення в перелік баз проходження практики соціальних служб, навчальних закладів, які працюють із представниками етнічних меншин; ведення робочих зошитів, де студенти самостійно описують результати своєї роботи, а потім на консультаціях, спільно 3 інструктором обговорюють позитивні аспекти і помилки; створення відеофільмів за результатами роботи; зустрічі студентів на базі агентства з представниками культурних, етнічних і расових груп для ознайомлення з проблемами етнічних меншин; відвідування культурних заходів міста, релігійних свят етнічних меншин та ін.) [3; 4; 5; 10].

Досліджено, що відсутність розроблених теоретичних засад практичної підготовки спеціальності соціального працівника пояснює розбіжності між змістом професійної освіти загалом і характером та організацією практичної підготовки зокрема. Однак аналіз навчальних планів підготовки бакалаврів (магістрів) соціальної роботи та навчальних програм дисциплін кожного циклу свідчить про те, що в межах фахової підготовки майбутніх фахівців практична підготовка не перевищує 30 \%. Вважаємо за доцільне при виробленні нових принципів i підходів до розробки та оновлення вітчизняних галузевих стандартів спеціальності акцентувати увагу на позитивний досвід практичної підготовки соціальних працівників у Польщі. Зазначений підхід особливу роль відіграє в умовах модернізації системи освіти України, доручення іiі до європейського і світового освітнього простору.

Впровадження практичного компоненту у підготовку соціальних працівників розпочато у КОГПА ім. Тараса Шевченка 3 2015/2016 н. р. Відповідно до навчального плану підготовки майбутніх соціальних працівників відведено 720 год. (24 кред.) від загального обсягу на проходження видів практик: навчально-ознайомлювальна - 90год. у ІІІсем., навчальна практика (у соціальних закладах та установах) - 120 год. у IV сем., навчально-педагогічна 3 додаткової кваліфікаиії - 120 год. у IV сем., переддипломна практика - 90 год. у III сем., 180 год. у VI сем.). На порядку денному удосконалення змістової 
Журнал«Герспективита іновації наукиљ

(Серія «Гедагогіка», Серія «Гиихологія»), Серія «Медицина»

№5(5) 2021

сторони практичного компоненту підготовки соціальних працівників відповідно до вітчизняних стандартів та міжнародних вимог до рамки кваліфікацій фахівця соціальноїсфери [4, с.202].

У навчальному плані 2018-2019 н. р. на рівнях підготовки майбутніх соціальних працівників «бакалавр-магістр» НУ «Львівська політехніка» відведено 765 год. (25,5 кред.) від загального обсягу на проходження різних видів практики: навчально-ознайомлювальна - 90 год. у IV сем., навчальна (виробнича) практика (у соціальних закладах та установах) - 225 год. у V сем., переддипломна практика за темою бакалаврської роботи - 135 год. у VIII сем. та переддипломна практика за темою магістерської роботи - 315 год. у XI (III) сем.). Важливо відзначити додаткове введення у програму підготовки соціальних працівників практикуму із соціальної роботи в обсязі 480 год. (210 год. аудиторних, з них - на III курсі, VI сем. - 90 год.; на IV курсі, VII сем. 120 год.). Для ефективної практичної підготовки створено мережу баз практики студентів спеціальності «Соціальна робота» - понад 30 закладів соціальної служби м. Львова [4, с.203].

У процесі викладання варіативної навчальної дисципліни «Соціальна освіта і соціальна робота у Польщі» [5] для майбутніх соціальних працівників у вітчизняних ЗВО (зокрема, в КОГПА та НУ ЛП) актуалізувалися питання: соціальної роботи в Республіці Польща як окремої галузі знань; зародження теорії і практики соціальної педагогіки як науки; становлення соціальної педагогіки як самостійної наукової дисципліни у вищій школі, фактори впливу на становлення і розвиток практичної підготовки соціальних працівників тощо. Впроваджувалися інтерактивні методи навчання із практичним спрямуванням освітнього процесу: лекції-дискусії, лекції із мультимедійною презентацією, проблемні лекції, презентації студентів, стендові доповіді, наглядові сесії та тренінги та під час практики.

Відповідно до нових стратегічних ліній розвитку вищої освіти Польщі, зважаючи на освітні тенденції та умови реформування (Закон про вищу освіту, 2018 р.)[9], прописано університетську автономію та визначено забезпечення гнучкості у внутрішній організаційній структурі. Для університетів упроваджено конкурси «Ініціативи передового досвіду науково-дослідним університетам» та «Регіональна ініціатива досконалості». Визначено нові вимоги до кадрової політики вищої школи, надання соціальних гарантій викладачу вищої школи та захисту інтелектуальної власності та авторського права. Запропоновано перевірку праць на унікальність за Єдиною системою «Антиплагіат», обов'язковою дляусіх $3 \mathrm{BO}$ та наукових установ, яка $\epsilon$ державною та безкоштовною. Таким чином, система вищої освіти Республіки Польща, і зокрема практичної підготовки соціального працівника, за останнє десятиліття пройшла складний шлях реформації, який доцільно взяти за зразок при подальшому реформуванні системи вищої освіти України.

Аналіз навчальних планів та програм підготовки соціальних працівників у польській вищій школі засвідчує, що автономія польських вишів дозволяє 
вносити певні корективи не лише в навчальні плани відповідно до запитів суспільства і регіональних особливостей, й у вибір напряму підготовки та форми навчання фахівця соціальної сфери залежно від регіональних потреб. 3 огляду на останні тенденції до самостійності вітчизняних університетів (Закон про вищу освіту України, 2014), цей підхід заслуговує на особливу увагу. Для забезпечення якості практичної підготовки та конкурентоздатності вітчизняного фахівця соціальної роботи може бути позитивна ідея впровадження курсів із вивчення другої іноземної мови на рівні В. 2 як дисципліни за вибором, a ii вибір повинен відбуватися 3 урахуванням регіонального аспекту.

3'ясовано, що доступність та ефективність практичної підготовки соціального працівника у вищій школі Польщі забезпечується через різновекторне впровадження поряд із традиційними інноващійних форм навчання: стаціонарне (studia stacjonarne), нестаціонарне (studia niestacjonarne), вільне (неформальне) (bezpłatne szkolenia) навчання; заочна (studia niestacjonarne, zaoczne), вечірня (niestacjonarne, wieczorowe), екстернатна (studia niestacjonarne, eksternistyczne) та дистанційна форми (E-Learning, або електронне навчання, Інтернет-навчання) навчання; індивідуальне (indywidualna organizacja studiow (IOS), szkolenia indywidualne), дуальне (studia dualne), додаткове (dodatkowe szkolenie) та інтегроване (інклюзивне) (zintegrowane szkolenie) навчання. Різновекторність форм навчання впроваджується у вітчизняну практику вищої школи, однак потребує дієвої мобільності i автономності на регіональному рівні. Так, у вітчизняній практичній підготовці волонтерів, працівників реабілітаційних центрів, які допомагають учасникам операції об’єднаних сил (ООС) та тимчасово переміщеним особам реабілітуватися, можна використати позитивний досвід польських 3ВО та громадських організацій щодо впровадження сучасних форм та методів комунікативної ресоціалізації, зорієнтованих на впровадження активних тренінгових технологій (зокрема, інтеграційно-мотивачійний тренінг), драматичних технік, транзакційних ігор та ігор з прийняття рішень, розв'язання соціальних проблем, вирішення міжособистісних конфліктівтощо.

Важливим кроком у реформуванні структури вищої освіти Польщі стала робота над стандартизацією навчання за трансферною системою європейських кредитів (ECTS), спрямована на підвищення мобільності навчання - як у часі (можливість вибору індивідуальної траєкторії навчання), так i у просторі (послідовне навчання у різних 3ВО), тобто принцип мобільності, який пропагується Свропейською комісією, має надати студентам можливість одержання знання за обраною спеціальністю в різних навчальних центрах (у країні поселення i за кордоном) на тому ж самому рівні освіти. Зазначені модернізаційні процеси відбуваються у вищій школі України, однак потребують інтенсифікації у запровадженні рамок кваліфікацій соціального працівника.

Безумовно, заслуговує на увагу кредитна система навчання у Республіці 
Польща, яка в останні десятиліття $є$ невід'ємним атрибутом вищої школи України, проте відрізняється за змістом. Наприклад, чотири кредити, які заплановані для вивчення навчальної дисципліни «Семінар із соціальної справедливості» (Школа соціальної роботи WM університету в Ольштині) включають теоретичне вивчення курсу, самостійну підготовку до занять (в тому числі під керівництвом викладачів), обов'язкову 30-годинну практику в соціальному агентстві, розробку електронних портфоліо, соціальних проєктів та ін. Як відомо, в Україні певна кількість кредитів передбачає їх розподіл на аудиторне навчання і самостійну роботу.

Вважаємо, що уваги заслуговує впровадження практичного компоненту спеціалізованих дисциплін в основний освітній процес підготовки соціальних працівників із врахуванням регіонального замовлення та потреб регіону. Досліджено, що у Польщі на старших курсах обсяг навчальних предметів за вибором становить близько 70\% від їх загальної кількості. В українських 3ВО вибіркові навчальні дисципліни становлять в середньому 25-40\%. У майбутньому, враховуючи польський досвід i надзвичайну актуальність проблеми практичної підготовки фахівців в Україні, планується доповнити навчальні програми підготовки соціальних працівників спеціальними практичними курсами татренінгами.

Практичний компонент професійної підготовки соціальних працівників у вищій школі Польщі зумовлений синергетично у суб'єкт-суб'єктній взаємодії закладу освіти, викладача вищої школи i студента, 3 прогнозованою орієнтацією на майбутню професійну співпрацю соціального працівника i клієнта. Такий підхід є складовою соціальної системи держави, що детермінує політичні, соціальні, освітні та особистісні перетворення. Із метою внесення змін, удосконалення, перегляду окремих iї елементів та способів їхньої взаємодії до неї можна застосовувати лише ті педагогічні впливи, які пов'язані 3 природними тенденціям їірозвитку. Польські вчені та практики визначають, що не менш важливим (або навіть більш важливим), ніж структурні зміни, $є$ перехід у професійному навчанні майбутніх соціальних працівників від педагогічної парадигми, сконщентрованої на процесі навчання, до орієнтації на вміння навчатись. Встановлено, що ефективність практичного навчання майбутніх соціальних працівників багато в чому залежить від змісту й характеру соціальної взаємодії студента $і$ його викладача-наставника вищої школи (у ролі ментора, тьютора, коуча, фасилітатора, едвайзера, консультанта) на засадах студентоцентризму; від технологій навчання та практичного застосування в освітньому процесі методів соціальної роботи, здійснення супроводу зростання майбутнього фахівця за індивідуальною програмою навчання і вмотивованої оцінки результатів діяльності; умов проходження практики.

За результатами дослідження простежено тенденції науково-методичного супроводу кафедр соціальної роботи щодо практичної підготовки соціальних працівників у Польщі: відповідність загальноєвропейській спрямованості до 
ранньої спеціальної підготовки всіх фахівців соціальної сфери; двосторонній зв’язок між розвитком наукової школи соціальної роботи та системою організації практичної підготовки; підготовка соціального працівника в навчальних закладах церкви; децентралізація управління професійною підготовкою; швидке реагування системи на зміни соціального характеру, запити регіонального ринку праці. Отже, структурно-системний аналіз джерельної бази наукового дослідження дозволив виявити, що суповід (нагляд) у теорії та на практиці підготовки польських соціальних працівників має свою специфіку, потребує вивчення та прогнозує можливості впровадження позитивного досвіду у професійну підготовку соціальних працівників в Україні.

В освітній процес ЗВО активно впроваджується європейський підхід щодо використання інноваційних, мультимедійних форм i методів освіти та залучення студентів до участі в європейських освітніх програмах. Як свідчать результати дослідження в Україні переважна більшість європейських і, зокрема польських нововведень у освіту, на сьогодні повністю прийнятна і процес їх впровадження уже розпочався і триває. Активно впроваджується дворівнева підготовка фахівців «бакалавр-магістр». У рамках міжнародної програми TEMПУC-TACIS виконується ряд пілотних проєктів, які стосуються автономії 3ВО, впровадження магістратури та докторантури за європейськими стандартами, формування системи внутрішнього контролю ЗВО за якістю освіти тощо.

Однією з детермінант професіоналізації професії соціального працівника у вищій школі Польщі в соціологічному плані $є$ теоретичні знання та практика. Закон про вищу освіту Польщі (2018) передбачає підготовку висококваліфікованого спеціаліста для різних галузей і сфер діяльності у вищій школі Польщі. Із цією метою у Законі вказано чіткі вимоги до проходження студентом практики щонайменше $50 \%$ від загального обсягу навчального плану [9]. На законодавчому рівні визначено діапазон обов 'язкових практичних навичок (практики) (240 год.) для майбутніх соціальних працівників та узгоджено до Рамкових вимог вмінь, навичок та соціальних компетенцій, етичних принципів діяльності, професійного та особистісного рівнів зростання. У вищій школі Польщі, де відбувається підготовка соціальних працівників,проходження студентом практики - це своєрідна форма практичного навчання, отримання знань через свій особистий досвід. У результаті наукового пошуку простежено тенденцію впровадження професійного навчання на практиці польських соціальних працівників на прогресивних підходах практичного досвіду у соціальній сфері міжнародного виміру [10].

Великий науковий доробок і численні пропозиції модернізації практичної підготовки соціальних працівників не можуть поки що знайти масового використання у ЗВО. Тому побудова системи практик не зазнала істотних змін, а тенденції удосконалення помітні у спробах експериментів 3 перенесенням 
найкращих зразків закордонного досвіду (зі США, Англії, Німеччини, Швеції тощо) до Польщі. Зокрема, спостерігається реалізація трьох моделей підготовки соціального працівника із включенням до неї видів практик та стажування: вивчення теорії 3 наступним формуванням практичних навичок; паралельне засвоєння теорії і проведення практик; передує практика, теоретичне навчання відбувається пізніше. Разом з тим, відзначимо належний рівень інтеграції теоретичної та практичної підготовки соціальних працівників у Польщі, яка досягається завдяки: тісній співпраці вищої школи і агентств та соціальних інституцій; спільній розробці навчальних планів; проведенню наглядових сесій та тренінгів для керівників практики на базі вишу; поділу навчального тижня на аудиторні заняття та відвідування агентства; проходженню практики паралельно з теорією.

Вартим для запозичення $\epsilon$ досвід організації практичного навчання студентів через досвід на практиці. Цілі практики студентів визначено Радою 3 освіти в галузі соціальної роботи, які враховуються в освітніх програмах вищої школи Польщі. Основним вмінням після проходження професійної практики у Польщі має бути здатність студента зібрати матеріали, необхідні для написання соціальних проєктів. Робота над соціальними проєктами майбутніх соціальних працівників корелюється із діючими программами соціального забезпечення, регіональними проєктами щодо необхідності дослідження актуальних соціальних проблем у регіоні. Такий досвід практикується в Україні, але не набув системного характеру.

Досліджено, що суб'єктами практичного навчання майбутніх соціальних працівників є: практикант (praktykant) - студент, опікун практики (opiekun praktyk) - викладач, координатор практики факультету (wydziałowy koordynator praktyk) - співробітник факультету, наставник студентів (ментор) (мentor paktykanta) - особа, призначена приймаючою установою і соціальне агентство. Результати проведеного дослідження дозволяють зауважити, що у соціальних агентствах Польщі велика увага почала приділятися навчанню i підтримці співробітників, які виконують функції наставника практики. Практикується повністю звільнення від практичної роботи 3 клієнтами i прикріплення до трьох або більше студентів.

У теорії і практиці польських вишів у практичному спрямуванні освітнього процесу простежено дієвість державних програм, міжнародних фондів та громадських організацій і комітетів. Відзначимо роль і значення державних програм, а також міжнародних фондів та громадських організацій $i$ комітетів у Республіці Польща, позитивний досвід яких має усі можливості для вивчення та можливого впровадження у вітчизняну систему соціальної політики та вищої освіти. Серед них: польськоамериканський фонд свободи (2000), стипендія імені Лейна Кіркланда (2000),«ЗЗміни в регіоні» - RITA (2000), програма навчальних візитів до Польщі (Study toursto Poland - STP) (2004), Варшавська літня євроатлантична академія (WEASA) (2013)[4, с. 427-430]. 
Для предметного поля наукового дослідження важливо вказати на досвід Державного фонду реабілітації осіб з обмеженими можливостями (Państwowy Fundusz Rehabilitacji Osób Niepełnosprawnych) [4, c.433]. Це цільовий фонд, ресурси якого призначені для професійної та соціальної реабілітації, трудового працевлаштування осіб з обмеженими можливостями. Існує також Фонд стипендій на навчання (Fundusz Stypendialnyi Szkoleniowy KUL) [4, с.434]. Метою першого Фонду $є$ сприяння соціальній та професійній реабілітаціїй активізація осіб з обмеженими можливостями. Основна мета діяльності забезпечення, становлення та розвиток сприятливих соціальних умов для соціалізації осіб з обмеженими можливостями. Найуспішніші програмами: «СтудентII -продовження освіти осіб з обмеженими можливостями»; «Дистаниійна та інші форми зайнятості осіб з обмеженими можливостями; «Комп'ютер для Гомера».

Висновки. Отже, практична підготовка соціальних працівників у польській вищій школі становить складний і динамічний процес. У ході дослідження виявлено позитивний досвід i здійснено аналіз практичних здобутків упровадження практичної підготовки соціальних працівників у вищій школі Польщі на рівні ліценціату та магістерських студій та окреслено можливості творчого використання позитивних надбань в освітньому процесі України.

До напрямків подальшої роботи відносимо забезпечення професійного самовдосконалення фахівців заявленої спеціальності засобами сучасних інноваційних технологій соціальної роботи тощо.

\section{Лimepamypa:}

1. Андрущенко В. П. Модернізація педагогічної освіти в країні в контексті Болонського процесу. Вища освіта України. 2014. № 1. С. 6-10.

2. Кремень В. Модернізація системи вищої освіти: соціальна цінність і вартість для України : [монографія]. Київ : Педагогічна думка, 2007. 257 с.

3. Бенера В. Є., Шевченко Ж. М. До питання професійної підготовки соціальних працівників в Україні. International Journal of innovative technologies in social science. (Польща, Варшава). 4 (8), Vol. 1. 2018. С. 59-62.

4. Бенера В. С., Шевченко Ж. М. Практична підготовка соціальних працівників у вищій школі Республіки Польща: [монографія]. Тернопіль: ФОП Паляниця В.А., 2020. 435 с.

5. Соціальна робота у Республіці Польща: навчально-методичний посібник / авт.-упор. В. Є. Бенера, Ж. М. Шевченко. Кременець: КОГПА, 2019. 248 с.

6. Безпалько О. В. Реалии и перспективы развития социальной педагогики в Украине. URL: http://elibrary.kubg.edu.ua/3366/1/O_Bezpalko_SPZH_6_IL.pdf

7. Горішна Н. М. Концептуальні засади навчання соціальних працівників: аналіз зарубіжного досвіду. Наук. зап. Терноп. нац. пед. ун-ту. Серія : Педагогіка. 2011. № 2. С. 230-235.

8. Суріна I. А. Професійна підготовка вчителів у контексті реформи вищої освіти в Польщі. URL: http://ps.stateuniversity.ks.ua/file/issue_65/51.pdf

9. Ustawa z dnia 3 lipca 2018 r. (Kancelaria Sejmu s. 1/104 04.09.2018 Dz.U. 2018 poz. 1669 USTAWA z dnia 3 lipca 2018 r.) URL:

http://prawo.sejm.gov.pl/isap.nsf/download.xsp/WDU20180001668/O/D20181668 
10. Шевченко Ж. М. Практична підготовка соціальних працівників у вищій школі Польщі: автореф. на здобуття наук. ступеня канд. пед. наук за спеціальністю 13.00 .01 «Загальна педагогіка та історія педагогіки». Криворізький державний педагогічний університет, м. Кривий Ріг, 2019. 20 с.

\section{References:}

1. Andrushhenko, V. P. (2014). Modernizacija pedagogichnoï osviti v kraïni v konteksti Bolons\&apos;kogo procesu [Modernization of pedagogical education in the country in the context of the Bologna process]. Vishha osvita Ukraïni-Higher education in Ukraine, 1, 6-10 [in Ukrainian].

2. Kremen\&apos;, V. (2007). Modernizacija sistemi vishhoï osviti: social\&apos;na cinnist\&apos; $i$ vartist\&apos; dlja Ukraïni [Modernization of the higher education system: social value and value for Ukraine]. Kiïv : Pedagogichna dumka [in Ukrainian].

3. Benera, V. E., Shevchenko, Zh. M. (2018). Do pitannja profesijnoï pidgotovki social\&apos;nih pracivnikiv v Ukraïni [On the issue of professional training of social workers in Ukraine]. International Journal of innovative technologies in social science - International Journal of innovative technologies in social science, 4 (8), 1. 2018, 59-62 [in Ukrainian].

4. Benera, V. C., Shevchenko, Zh. M. (2020). Praktichna pidgotovka social\&apos;nih pracivnikiv $u$ vishhij shkoli Respubliki Pol\&apos;shha [Practical training of social workers in higher education in the Republic of Poland]. Ternopil\&apos;: FOP Paljanicja V.A. [in Ukrainian].

5. Benera, V. E. , Shevchenko, Zh. M. (2019). Social\&apos;na robota $u$ Respublici Pol\&apos;shha [Social work in the Republic of Poland]. KOGPA [in Ukrainian].

6. Bezpal\&apos;ko, O. V. Realii $i$ perspektivy razvitija social\&apos;noj pedagogiki $v$ Ukraine [Realities and prospects for the development of social pedagogy in Ukraine]. Retrived from http://elibrary.kubg.edu.ua/3366/1/O_Bezpalko_SPZh_6_IL.pdf [in Ukrainian].

7. Gopishna, N. M. (2011). Konceptual\&apos;ni zasadi navchannja social\&apos;nih pracivnikiv: analiz zarubizhnogo dosvidu [Conceptual principles of teaching social workers: analysis of foreign experience]. Nauk. zap. Ternop. nac. ped. un-tu. Serija : Pedagogika - Science. zap. Ternopil. nat. ped. un-tu. Series: Pedagogy, 2, 230-235 [in Ukrainian].

8. Curina, I. A. Profesijna pidgotovka vchiteliv $u$ konteksti reformi vishhoï osviti $v$ Pol\&apos;shhi [Teacher training in the context of higher education reform in Poland]. Retrived from http://ps.stateuniversity.ks.ua/file/issue_65/51.pdf [in Ukrainian].

9. Ustashha z dnia 3 lipca 2018 r. (Kancelaria Sejmu s. 1/104 04.09.2018 Dz.U. 2018 poz. 1669 USTAShhA z dnia 3 lipca 2018 r.) URL:

http://prashho.sejm.gov.pl/isap.nsf/doshhnload.hsp/ShhDU20180001668/O/D20181668

10. Shevchenko, Zh. M. (2019). Praktichna pidgotovka social\&apos;nih pracivnikiv u vishhij shkoli Pol\&apos;shhi [Practical training of social workers in higher education in Poland]. Extended abstract of candidate's thesis. Krivij Rig: Krivoriz\&apos; kij derzhavnij pedagogichnij universitet [in Ukrainian]. 